\title{
Lactobacillus pobuzihii sp. nov., isolated from pobuzihi (fermented cummingcordia)
}

\author{
Yi-Sheng Chen, ${ }^{1,2}$ Mika Miyashita, ${ }^{3}$ Ken-ichiro Suzuki, ${ }^{3}$ Hajime Sato, ${ }^{3}$ \\ Jar-Sheng $\mathrm{Hsu}^{4}$ and Fujitoshi Yanagida ${ }^{2}$
}

Correspondence
Yi-Sheng Chen
yisheng@mail.mcu.edu.tw

Lactic acid bacteria (LAB) are widely distributed in foods in Taiwan such as suan-tsai (fermented mustard) (Chen et al., 2006a) and dochi (fermented black beans) (Chen et al., 2006b). Pediococcus pentosaceus, Tetragenococcus halophilus and Enterococcus faecium have been isolated from these foods and possibly play important roles in their souring and ripening. Pobuzihi is a popular traditional food sold in both traditional markets and supermarkets in Taiwan. It is produced by fermenting cummingcordia, a grain product. Pobuzihi is produced by two different methods that yield different flavours. In one method (method A), harvested cummingcordia is washed, boiled, mixed with salt $(\mathrm{NaCl})$ and then packed in containers while hot. After cooling, congealed cummingcordia is removed from the containers and placed in urns containing a salt solution. Usually, fermentation continues for at least 10 days, but some producers maintain a longer fermentation time. In the other method (method B), cummingcordia is boiled and dried, and then mixed with sugar, salt, soy and sake (rice

\section{Abbreviation: $L A B$, lactic acid bacteria}

The GenBank/EMBL/DDBJ accession numbers for the 16S rRNA gene sequences of isolates $\mathrm{E} 100301^{\top}, \mathrm{E} 100309, \mathrm{E} 100311, \mathrm{E} 100313$, E100318, E100326 and E100329 are AB326358-AB326364, respectively. wine). Finally, the mixture is packed in bottles, sealed and fermented for 15 days or longer. In both methods A and B, the fermentations are carried out at room temperature. Pobuzihi is used both as a food and as a seasoning. The fermentation process of pobuzihi has not been studied in detail, despite the popularity of the product. The present study deals with the isolation of LAB predominating in pobuzihi and their taxonomic characterization as representing a novel species of the genus Lactobacillus.

Twelve pobuzihi samples were collected from one factory (Yunlin county, Taiwan), traditional markets and supermarkets. Eight of the samples were fermented with method $A$ and four with method B. LAB were isolated from pobuzihi by using the methods described by Chen et al. (2006a). MRS broth (Difco) containing $6 \% \mathrm{NaCl}$ was used for isolation. Cultivation for isolation was carried out anaerobically at $37{ }^{\circ} \mathrm{C}$. The purity of the isolates was confirmed by spreading on an MRS agar plate containing $6 \% \mathrm{NaCl}$. Lactobacillus acidipiscis strains NBRC $102163^{\mathrm{T}}$ and NBRC 102164 were used as reference strains. $L$. acidipiscis NBRC $102163^{\mathrm{T}}$ was isolated from fermented fish in Thailand (Tanasupawat et al., 2000, 2002). Strain NBRC 102164 was isolated from halloumi cheese produced in Cyprus (Lawson et al., 2001) and is the type strain of Lactobacillus cypricasei, which is considered a heterotypic 
synonym of L. acidipiscis (Naser et al., 2006). These two strains were cultured for 2 days in MRS broth at $37^{\circ} \mathrm{C}$. All strains were stored at $-80{ }^{\circ} \mathrm{C}$ in $10 \%$ skimmed milk.

Tests of phenotypic characteristics such as isomers of lactic acid produced, lactic acid fermentation type, salt tolerance and growth temperature range were carried out based on the procedures described by Chen et al. (2006a, b). Tests of acid production from carbohydrates were performed by using the API 50CHL fermentation kit (bioMérieux).

Restriction fragment length polymorphism (RFLP) analysis of 16S rRNA genes was used for preliminary classification of the novel bacterial isolates (Ramos \& Harlander, 1990; Gurtler et al., 1991; Johansson et al., 1995). PCR was carried out by using a TaKaRa Ex Taq gene amplification PCR kit (Takara Bio Inc.) and was performed on a Gene Amp PCR System 9700 (Perkin Elmer) following the methods described by Chen et al. (2005). RFLP analysis of the $16 \mathrm{~S}$ rRNA gene was carried out according to the methods described by Chen et al. (2005). In the present study, four restriction enzymes were used: AccII (CG/CG), HaeIII (GG/ CC), AluI (AG/CT) and MspI (C/CGG) (Sato et al., 2000; Christensen et al. 2004; Chen et al., 2006b).

Sequencing of $16 \mathrm{~S}$ rRNA genes was carried out as described by Nakagawa et al. (2002) by using the following primers: 5'-GAGTTTGATCCTGGCTCAG-3' (9F), 5'-GGATTAGATACCCTGGTAGTC-3' (785F), 5'-TACCAGGGTATCTAATCC-3' (802R) and 5'-GGCTACCTTGTTACGA-3' (1510R). DNA sequencing was performed on a model ABI PRISM 3100 Genetic Analyzer (Applied Biosystems).

Multiple sequence alignments and construction of phylogenetic trees were performed by using the CLUSTAL X version 1.83 software package (Thompson et al., 1997) based on the neighbour-joining method (Saitou \& Nei, 1987) and $K_{\text {nuc }}$ values (Kimura, 1980). Alignments were subsequently modified manually with Se-Al version 2.0 (Rambaut, 1996). Alignment gaps and unidentified base positions were not taken into consideration in the calculations. The topological robustness of the phylogenetic trees was evaluated by a bootstrap resampling method based on 1000 replicates (Felsenstein, 1985).

Inter- and intraspecific DNA-DNA hybridizations were carried out with photobiotin-labelled probes in microplate wells, as described by Ezaki et al. (1989). Fluoroskan Ascent (Thermo Fisher Scientific, Inc.) was used for fluorescence measurements. Hybridization was carried out at $49.5{ }^{\circ} \mathrm{C}$ in $2 \times$ SSC buffer containing $25 \%$ formamide. The DNA $\mathrm{G}+\mathrm{C}$ content was subsequently determined according to Mesbah et al. (1989).

Twenty-one isolates were obtained from the pobuzihi samples. These isolates showed the same 16S rRNA gene RFLP patterns when digested with AccII, HaeIII, AluI and MspI. However, the patterns when digested with HaeIII, AluI and MspI were different from those of $L$. acidipiscis NBRC $102163^{\mathrm{T}}$ and NBRC 102164 (Fig. 1).

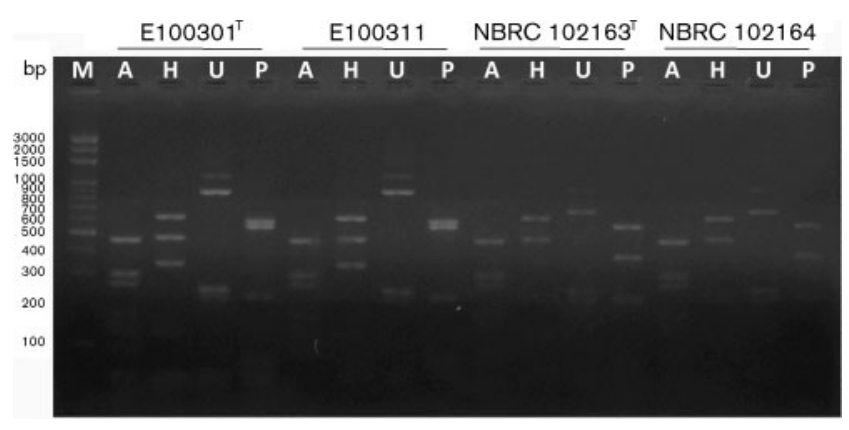

Fig. 1. RFLP patterns of Accll, Haell, $A / u$ and Mspl digests of the 16S rRNA genes of isolates $\mathrm{E} 100301^{\top}$ and $\mathrm{E} 100311$ and $L$. acidipiscis strains NBRC $102163^{\top}$ and NBRC 102164. Lanes: M, size marker; A, Accll digests; H, Haell digests; U, Alul digests; P, Mspl digests.

$16 \mathrm{~S}$ rRNA gene sequences (approximately $1489 \mathrm{nt}$ ) were determined for seven randomly selected isolates: $\mathrm{E} 100301^{\mathrm{T}}$, E100309, E100311, E100313, E100318, E100326 and E100329. The seven pobuzihi isolates shared $100 \% 16 \mathrm{~S}$ rRNA gene sequence similarity. As shown in Fig. 2, results of phylogenetic analysis confirmed the position of the seven isolates as closely related to $L$. acidipiscis NBRC $102163^{\mathrm{T}}$ (98.46\% 16S rRNA gene sequence similarity). Lower levels of $16 \mathrm{~S}$ rRNA gene sequence similarity were obtained with Lactobacillus salivarius NBRC $102160^{\mathrm{T}}(93.42 \%)$ and Lactobacillus aviarius subsp. aviarius NBRC $102162^{\mathrm{T}}$ (93.15\%). The 16S rRNA gene sequence was also analysed by using the maximum-parsimony (Fitch, 1971, 1977) and maximum-likelihood (Felsenstein, 1981) methods. Results similar to those with the neighbour-joining method were obtained (Fig. 2).

All 21 pobuzihi isolates grew in a medium with $10 \%(\mathrm{w} / \mathrm{v})$ $\mathrm{NaCl}$ and showed homolactic fermentation and production of L-lactic acid. The results obtained with the API50 CHL fermentation kit indicated that all the pobuzihi isolates were clearly different from $L$. acidipiscis strains NBRC $102163^{\mathrm{T}}$ and NBRC 102164 in terms of acid production from L-arabinose, rhamnose, mannitol, lactose and 5ketogluconate (Table 1). The DNA G $+\mathrm{C}$ content of strain $\mathrm{E} 100301^{\mathrm{T}}$ was $37.2 \mathrm{~mol} \%$, slightly lower than that of $L$. acidipiscis NBRC $102163^{\mathrm{T}}$ (38.9 mol\%).

DNA-DNA hybridization experiments were performed by using DNA derived from isolates E100301 ${ }^{\mathrm{T}}$ and E100311 and L. acidipiscis strains NBRC $102163^{\mathrm{T}}$ and NBRC 102164. Levels of DNA-DNA relatedness between the two pobuzihi isolates and the L. acidipiscis strains were $17 \%$ and below, indicating that the new isolates are not members of $L$. acidipiscis (Table 2), supporting the result of $16 \mathrm{~S}$ rRNA gene sequence analyses.

The data presented here indicate the independent status of the pobuzihi isolates in the genus Lactobacillus. Based on the results of DNA-DNA hybridization, the 21 pobuzihi isolates represent a species that is clearly separated from its 


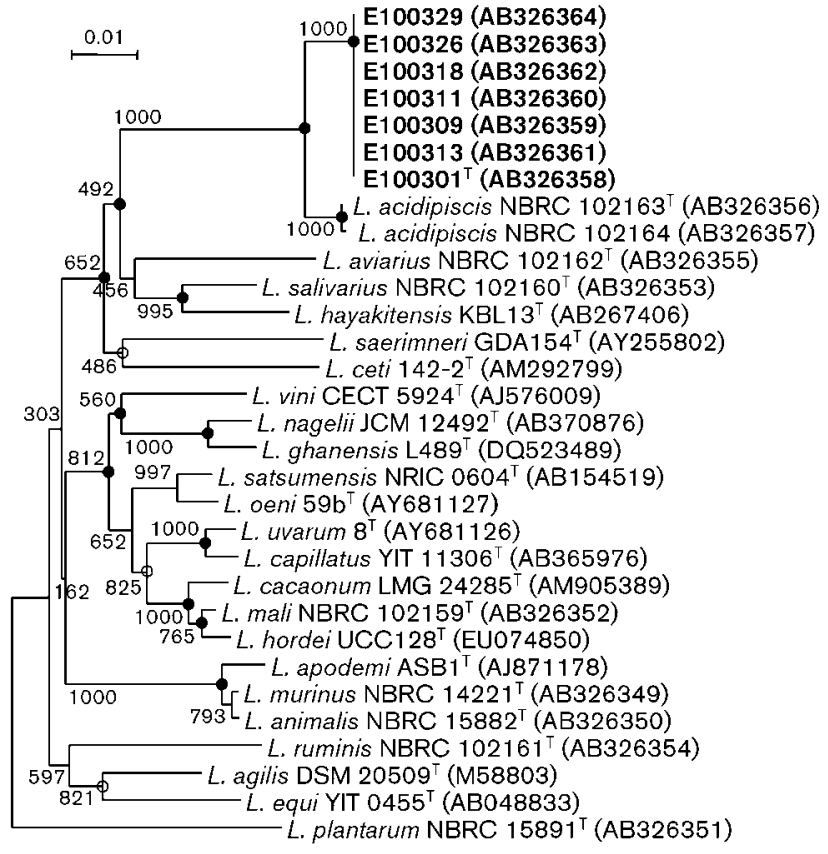

Fig. 2. Neighbour-joining phylogenetic tree based on $16 \mathrm{~S}$ rRNA gene sequence comparisons showing the position of strain $\mathrm{E} 100301^{\top}$ and related lactobacilli. Bootstrap values are indicated at branch points based on 1000 replications. The sequence of Lactobacillus plantarum NBRC $15891^{\top}$ was used as an outgroup. GenBank accession numbers are given in parentheses. Filled circles indicate nodes that were also recovered in maximumparsimony and maximum-likelihood analyses, and open circles indicate nodes that were also recovered in the maximum-likelihood analysis. Bar, 1 substitution per 100 nucleotide positions. closest phylogenetic neighbours and has phenotypic characteristics that clearly distinguish it from $L$. acidipiscis (strains NBRC $102163^{\mathrm{T}}$ and NBRC 102164). More detailed characteristics are given in the species description below and in Table 1.

In conclusion, the 21 isolates from pobuzihi are considered to represent a single novel species of the genus Lactobacillus, for which the name Lactobacillus pobuzihii sp. nov. is proposed.

\section{Description of Lactobacillus pobuzihii sp. nov.}

Lactobacillus pobuzihii [po.bu.zi'hi.i. N.L. gen. n. pobuzihii referring to the isolation of the type strain from pobuzihi (fermented cummingcordia)].

Cells are Gram-stain-positive rods, approximately $0.5 \times 2.2-3.9 \mu \mathrm{m}$. Colonies on MRS agar containing $6 \%$ $\mathrm{NaCl}$ are opaque with smooth edges and approximately $2 \mathrm{~mm}$ in diameter after $4-5$ days of growth at $37^{\circ} \mathrm{C}$. Facultatively anaerobic. Catalase-negative. Utilizes D-glucose homofermentatively but does not produce gas from glucose. Produces L-lactic acid from glucose. Grows at 30 $37{ }^{\circ} \mathrm{C}$ but not at 15 or $45^{\circ} \mathrm{C}$. Grows in the presence of $10 \%$ $\mathrm{NaCl}$. Acid is produced from D-glucose, ribose, D-fructose, L-arabinose, trehalose, rhamnose, maltose, lactose, 5ketogluconate and $\mathrm{N}$-acetylglucosamine. Most known isolates produce acid from glycerol (19/21), D-tagatose $(19 / 21)$ and cellobiose $(20 / 21)$. Acid is not produced from mannitol, erythritol, D-xylose, L-xylose, adonitol, D-arabinose, methyl $\beta$-xyloside, L-sorbose, dulcitol, inositol, sorbitol, methyl $\alpha$-D-mannoside, amygdalin, melibiose, inulin, melezitose, raffinose, glycogen, xylitol, D-arabitol,

Table 1. Physiological characteristics of the pobuzihi isolates and L. acidipiscis strains

All strains produce L-lactic acid homofermentatively. +, Positive; w, weakly positive; -, negative; ND, not determined. Numbers indicate the number of isolates that show a positive reaction.

\begin{tabular}{|c|c|c|c|c|}
\hline \multirow[t]{2}{*}{ Characteristic } & \multicolumn{2}{|c|}{ L. pobuzihii sp. nov. } & \multicolumn{2}{|c|}{ L. acidipiscis } \\
\hline & $\mathrm{E} 100301^{\mathrm{T}}$ & Twenty other isolates & NBRC $102163^{T}$ & NBRC 102164 \\
\hline DNA G $+C$ content $(\mathrm{mol} \%)$ & 37.2 & ND & 38.9 & 38.9 \\
\hline \multicolumn{5}{|l|}{ Acid production from: } \\
\hline Glycerol & + & 18 & - & + \\
\hline L-Arabinose & + & + & - & - \\
\hline Rhamnose & + & + & - & - \\
\hline Mannitol & - & - & + & - \\
\hline Maltose & + & + & + & + \\
\hline Lactose & + & + & - & - \\
\hline D-Turanose & - & - & + & - \\
\hline 5-Ketogluconate & + & + & - & - \\
\hline D-Tagatose & + & 18 & - & - \\
\hline Amygdalin & - & - & - & $\mathrm{W}$ \\
\hline Arbutin & - & 5 & $\mathrm{w}$ & + \\
\hline Cellobiose & + & 19 & - & + \\
\hline
\end{tabular}


Table 2. Levels of DNA-DNA relatedness between selected pobuzihi isolates and $L$. acidipiscis strains

\begin{tabular}{|c|c|c|c|c|}
\hline \multirow[t]{2}{*}{ Source of unlabelled DNA } & \multicolumn{4}{|c|}{$\begin{array}{c}\text { DNA-DNA hybridization (\%) } \\
\text { with labelled DNA from: }\end{array}$} \\
\hline & 1 & 2 & 3 & 4 \\
\hline 1. $\mathrm{E} 100301^{\mathrm{T}}$ & 100 & 86 & 13 & 16 \\
\hline 2. E100311 & 86 & 100 & 11 & 17 \\
\hline 3. L. acidipiscis NBRC $102163^{\mathrm{T}}$ & 10 & 15 & 100 & 107 \\
\hline 4. L. acidipiscis NBRC 102164 & 11 & 15 & 91 & 100 \\
\hline
\end{tabular}

L-arabitol, D-fucose, L-fucose or D-turanose. The DNA $\mathrm{G}+\mathrm{C}$ content of the type strain is $37.2 \mathrm{~mol} \%$.

The type strain, E100301 ${ }^{\mathrm{T}}\left(=\right.$ RIFY $6501^{\mathrm{T}}=\mathrm{NBRC} 103219^{\mathrm{T}}$ $\left.=\mathrm{KCTC} 13174^{\mathrm{T}}\right)$, was isolated from fermented cumming cordia (pobuzihi). The species includes another 20 isolates from pobuzihi.

\section{Acknowledgements}

We thank the Hua-tai Sauce Co., Ltd (Yunlin county, Taiwan), for supplying pobuzihi samples.

\section{References}

Chen, Y.-S., Yanagida, F. \& Shinohara, T. (2005). Isolation and identification of lactic acid bacteria from soil using an enrichment procedure. Lett Appl Microbiol 40, 195-200.

Chen, Y.-S., Yanagida, F. \& Hsu, J.-S. (2006a). Isolation and characterization of lactic acid bacteria from suan-tsai (fermented mustard), a traditional fermented food in Taiwan. J Appl Microbiol 101, 125-130.

Chen, Y.-S., Yanagida, F. \& Hsu, J.-S. (2006b). Isolation and characterization of lactic acid bacteria from dochi (fermented black beans), a traditional fermented food in Taiwan. Lett Appl Microbiol 43, 229-235.

Christensen, J. E., Reynolds, C. E., Shukla, S. K. \& Reed, K. D. (2004). Rapid molecular diagnosis of Lactobacillus bacteremia by terminal restriction fragment length polymorphism analysis of the $16 \mathrm{~S}$ rRNA gene. Clin Med Res 2, 37-45.

Ezaki, T., Hashimoto, Y. \& Yabuuchi, E. (1989). Fluorometric deoxyribonucleic acid-deoxyribonucleic acid hybridization in microdilution wells as an alternative to membrane filter hybridization in which radioisotopes are used to determine genetic relatedness among bacterial strains. Int J Syst Bacteriol 39, 224-229.

Felsenstein, J. (1981). Evolutionary trees from DNA sequences: a maximum likelihood approach. J Mol Evol 17, 368-376.

Felsenstein, J. (1985). Confidence limits on phylogenies: an approach using the bootstrap. Evolution 39, 783-791.
Fitch, W. M. (1971). Toward defining the course of evolution: minimum change for a specific tree topology. Syst Zool 20, 406-416.

Fitch, W. M. (1977). On the problem of discovering the most parsimonious tree. Am Nat 111, 223-257.

Gurtler, V., Wilson, V. A. \& Mayall, C. (1991). Classification of medically important clostridia using restriction endonuclease site differences of PCR-amplified $16 S$ rDNA. J Gen Microbiol 137, 26732679.

Johansson, M. L., Quednau, M., Ahrne, S. \& Molin, G. (1995). Classification of Lactobacillus plantarum by restriction endonuclease analysis of total chromosomal DNA using conventional agarose gel electrophoresis. Int J Syst Bacteriol 45, 670-675.

Kimura, M. (1980). A simple method for estimating evolutionary rates of base substitutions through comparative studies of nucleotide sequences. J Mol Evol 16, 111-120.

Lawson, P. A., Papademas, P., Wacher, C., Falsen, E., Robinson, R. \& Collins, M. D. (2001). Lactobacillus cypricasei sp. nov., isolated from Halloumi cheese. Int J Syst Evol Microbiol 51, 45-49.

Mesbah, M., Premachandran, U. \& Whitman, W. B. (1989). Precise measurement of the $\mathrm{G}+\mathrm{C}$ content of deoxyribonucleic acid by highperformance liquid chromatography. Int J Syst Bacteriol 39, 159-167.

Nakagawa, Y., Sakane, T., Suzuki, M. \& Hatano, K. (2002). Phylogenetic structure of the genera Flexibacter, Flexithrix, and Microscilla deduced from 16S rRNA sequence analysis. J Gen Appl Microbiol 48, 155-165.

Naser, S. M., Vancanneyt, M., Hoste, B., Snauwaert, C. \& Swings, J. (2006). Lactobacillus cypricasei Lawson et al. 2001 is a later heterotypic synonym of Lactobacillus acidipiscis Tanasupawat et al. 2000. Int J Syst Evol Microbiol 56, 1681-1683.

Rambaut, A. (1996). Se-Al: Sequence Alignment Editor version 1.0 $\alpha 1$. Distributed by the author. Department of Zoology, University of Oxford, Oxford, UK. http://evolve.zoo.ox.ac.uk/

Ramos, M. S. \& Harlander, S. K. (1990). DNA fingerprinting of lactococci and streptococci used in dairy fermentations. Appl Microbiol Biotechnol 34, 368-374.

Saitou, N. \& Nei, M. (1987). The neighbor-joining method: a new method for reconstructing phylogenetic trees. Mol Biol Evol 4, 406425.

Sato, H., Yanagida, F., Shinohara, T. \& Yokotsuka, K. (2000). Restriction fragment length polymorphism analysis of $16 \mathrm{~S}$ rRNA genes in lactic acid bacteria isolated from red wine. J Biosci Bioeng $\mathbf{9 0}$, 335-337.

Tanasupawat, S., Shida, O., Okada, S. \& Komagata, K. (2000). Lactobacillus acidipiscis sp. nov. and Weissella thailandensis sp. nov., isolated from fermented fish in Thailand. Int J Syst Evol Microbiol 50, 1479-1485.

Tanasupawat, S., Thongsanit, J., Okada, S. \& Komagata, K. (2002). Lactic acid bacteria isolated from soy sauce mash in Thailand. J Gen Appl Microbiol 48, 201-209.

Thompson, J. D., Gibson, T. J., Plewniak, F., Jeanmougin, F. \& Higgins, D. G. (1997). The CLUSTAL_X windows interface: flexible strategies for multiple sequence alignment aided by quality analysis tools. Nucleic Acids Res 25, 4876-4882. 